\title{
Disseminated cutaneous larva migrans in a 7-year-old patient
}

\section{Larva migrans cutânea disseminada em paciente de 7 anos de idade}

\author{
Victor Valente Lopes ${ }^{1}$ (D) Luís Arthur Brasil Gadelha Farias ${ }^{1}$ (D), Nina Brunet Saraiva Rodrigues ${ }^{3}$ (D), Andrea Pinheiro de Moraes ${ }^{3} \mathbb{B}$ \\ Robério Dias Leite ${ }^{2,3}$ (D) Glaúcia Maria Lima Ferreira ${ }^{3}$ (D) \\ 1. Discente da Faculdade de Medicina na Universidade Federal do Ceará (UFC), Fortaleza, CE, Brasil. 2. Docente do curso de Medicina na Universidade \\ Federal do Ceará (UFC), Fortaleza, CE, Brasil. 3. Hospital São José de Doenças Infecciosas (HSJ), Fortaleza, CE, Brasil.
}

\begin{abstract}
Introduction: Cutaneous larva migrans is a cutaneous infestation caused by zoonotic nematode larvae commonly due to hookworms such as the Ancylostoma braziliense. Case report: Herein we report a case of a 7-year-old child to the Emergency Department complaining of erythematous papular itching lesions on his right elbow, wrist and knee. He had no previous history of contact with sand or animals. The lesions in his right elbow presented impetiginization. Ivermectin $200 \mathrm{mcg} / \mathrm{kg} /$ day treatment was initiated and oxacillin associated. On the third day of treatment, the patient was discharged with complete resolution of the lesions. Coclusion: The reported case assumes importance because it is a common and benign disease, but due to an unusual presentation was not diagnosed earlier. The disseminated form commonly may require hospitalization and prolonged treatment as presented.
\end{abstract}

Key words: Larva migrans. Ectoparasitic Infestations. Dermatology. Infectious Diseases Medicine. Pediatrics.

\section{Resumo}

Introdução: A larva migrans cutânea é uma infestação cutânea causada por larvas de nematoides zoonóticos comumente causadas por ancilostomídeos como o Ancylostoma braziliense. Relato de caso: Aqui, relatamos o caso de uma criança de 7 anos de idade levada ao Departamento de Emergência, queixando-se de lesões eritematosas de prurido no cotovelo, punho e joelho direitos. Negava história prévia de contato com areia ou animais. As lesões no cotovelo direito apresentavam impetiginização. Ivermectina $200 \mathrm{mcg} / \mathrm{kg} /$ dia foi iniciada e oxacilina associada. No terceiro dia de tratamento, o paciente recebeu alta com resolução completa das lesões. Conclusão: 0 caso relatado assume importância por ser uma doença comum e benigna, mas devido a uma apresentação incomum não foi diagnosticada precocemente. A forma disseminada comumente pode requerer hospitalização e tratamento.

Palavras-chave: Larva migrans. Ectoparasitoses. Dermatologia. Infectologia. Pediatria.

\section{INTRODUCTION}

Cutaneous larva migrans is a cutaneous infestation caused by zoonotic nematode larvae, mainly canine or feline parasites, most commonly due to hookworms such as the Ancylostoma braziliense. These organisms are usually found in tropical and subtropical climate regions ${ }^{1,2}$. The zoonotic larva cannot reproduce in humans, since they are incidental hosts. The filariform larvae wander around in the skin without being able to pass the basal membrane in the skin and enter the organism. Unlike the anthropophilic hookworms, Necator americanus and A. duodenalis, those larvae cannot produce proteolytic enzymes, such as hyaluronidases and proteases, thus they are confined to the epidermis ${ }^{1}$. Although it is a common and benign condition, cases with disseminated manifestations are also described with potential complications ${ }^{3}$.

Herein we report a case of a 7-year-old patient with clinical diagnosis of a Disseminated cutaneous larva migrans resolved after prolonged antiparasitic treatment.

\section{CASE REPORT}

\section{A 7 year-old boy presented to the Emergency Department}

(ED) complaining of erythematous papular itching lesions in his right elbow and wrist (Figure 1), on his right knee and on the left side of his face. The symptoms began 20 days ago, when topical corticosteroids were applied to the lesions, which modified their original appearance. On physical examination, an important periarticular edema associated with movement limitation and pain with passive manipulation of the elbow was observed. Furthermore, the lesions on his right elbow presented impetiginization (Figure 2.A). Although the elbow lesion didn't have a typical aspect, at careful examination through palpation, we noted an irregular, slightly elevated track interspersed by scar tissue with considerable secondary infection. On the knee, there was an erythematous serpiginous lesion that lead to the clinical diagnosis of disseminated cutaneous larva migrans (Figure 3.A). Ivermectin $200 \mathrm{mcg} / \mathrm{kg} /$ day treatment was initiated, but a new lesion appeared on his face by the end of the first day, and treatment was prolonged for 3 (three) consecutive days. An elbow ultrasound was performed, which discarded the possibility of joint infection. Additionally, as there were signs of secondary bacterial infection such as erythema and pain, treatment with oxacillin was associated. On the third day of treatment the patient was discharged with complete resolution of the lesions (Figure 2.B and Figure 3.B).

Correspondência: Luís Arthur Brasil Gadelha Farias. Rua. Alexandre Baraúna, 949 - Rodolfo Teófilo, Fortaleza - CE, 60430-160. Fortaleza, CE, Brasil. E-mail: luisarthurbrasilk@gmail.com

Conflito de interesse: Não há conflito de interesse por parte de qualquer um dos autores.

Recebido em: 7 Jun 2018; Revisado em: 29 Jun 2018; 2 Ago 2018; Aceito em: 4 Ago 2018 
Figure 1. Erythematous serpiginous lesions on right wrist.

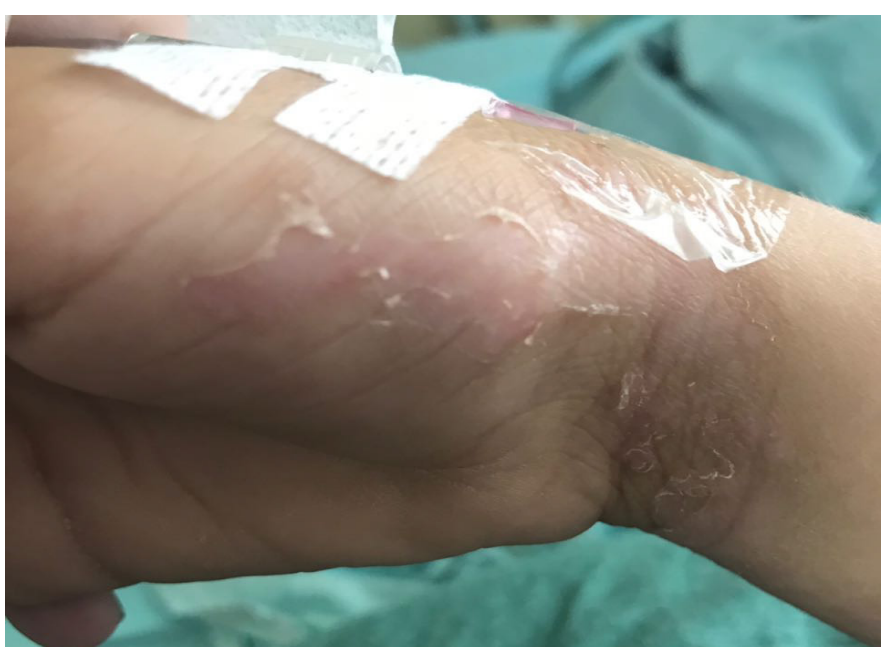

Figure 2. A. Erythematous and descamative lesions on right elbow. Notice the serpiginous lesions on the edge of the lesion. B. Cicatricial aspect after 3-day regimen of Ivermectina.

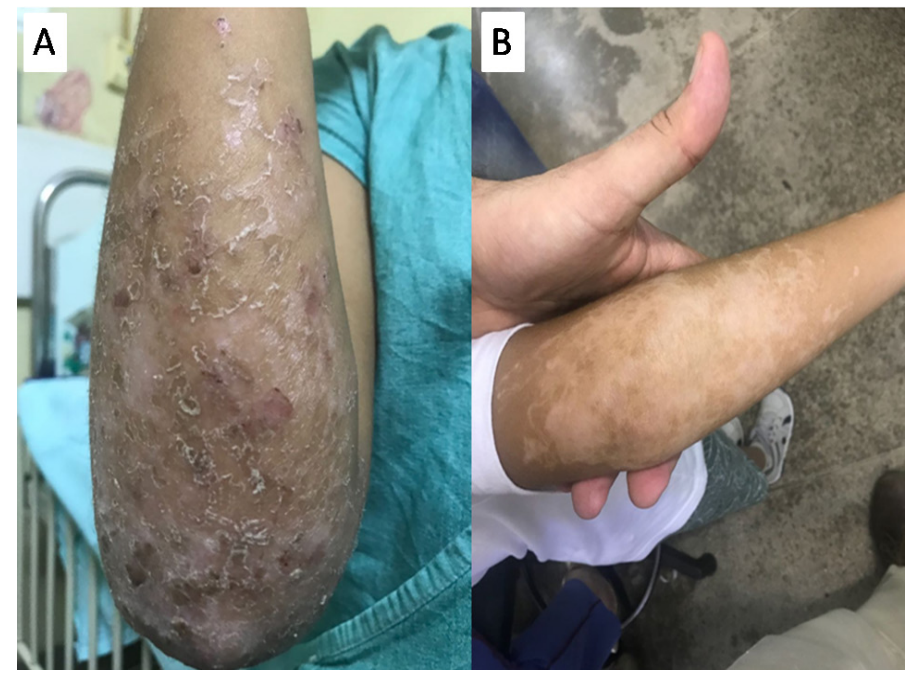

Figure 3. A. Erythematous serpiginous lesions on the right knee and thigh. B. Cicatricial aspect of the lesion after the 3-day regimen of Ivermectina.

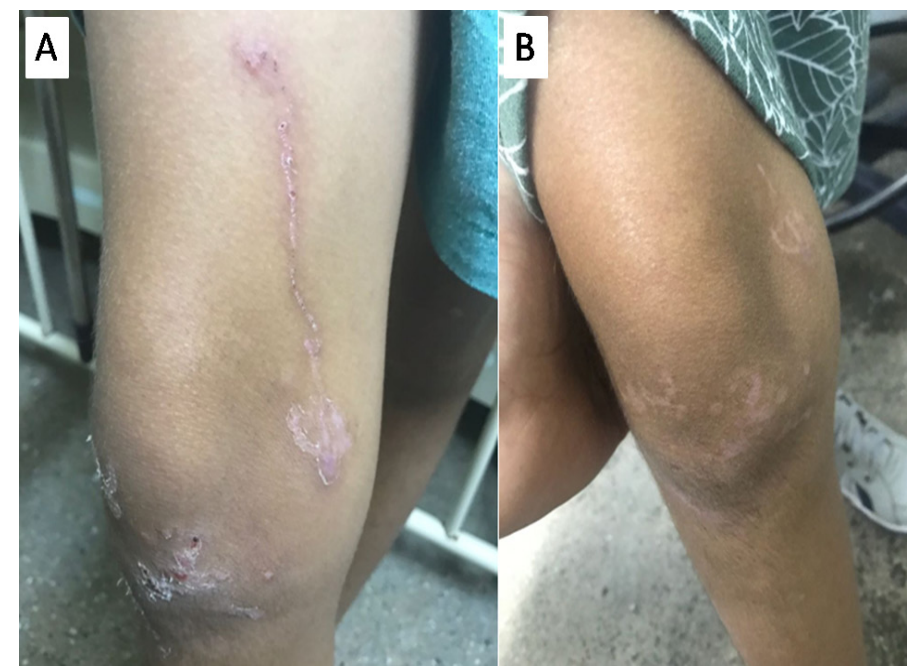

\section{DISCUSSION}

Larva migrans is present in many subtropical and tropical countries with high prevalence in resource-poor communities ${ }^{4}$. Larva migrans cutanea has been described on the whole Brazilian territory as affecting commonly children as in case reported $^{5}$. While migrating through the skin, the larvae produce a typical pruritic erythematous papule serpiginous track, which is considered a pathognomonic signal ${ }^{6}$. Vesiculo-bullous lesions can develop in about 10 percent of cases, and hookworm folliculitis may be present in five percent of cases, delaying the diagnosis $^{7,8}$. Pulmonary involvement, although rare, has been described as well ${ }^{9}$. The presented elbow injuries in the case were not typical and it was difficult to perceive the serpiginous aspect at the edges of the lesion. The knee injury, however, was typical and highly suggestive of the diagnosis.

The diagnosis is based on clinical history and physical examination. Infected patients typically have a history of exposure to contaminated soil or sand, or traveling to tropical or subtropical climate regions ${ }^{10}$. In the presented case, there is no previous history of contact with sand or animals which was a confound fact despite the patient's age. Our main hypothesis is that the patient may have been inadvertently contaminated on beaches or clay/ground floors. In addition to the presence of typical lesions eosinophilia may also be present ${ }^{1,6}$.

Larva migrans is usually a self-limited disease. Treatment is indicated because of the intense pruritus and the risk of a possible super infection ${ }^{6}$. A single dose of oral ivermectin results in cure in $94-100 \%$ of the patients and for hookworm folliculitis it may be necessary a second dose. A 3-day regimen of albendazole is also effective. For extensive lesions it may be necessary a 7-day course. Topical agents, such as thiabendazole and albendazole, are also an alternative, especially in localized disease ${ }^{6,11,12}$. Ivermectin advantages are the broad parasitic spectrum, reaching Strongyloidis stercoralis and other parasites. Although uncommon, there are reports of larva migrans syndrome caused by S. stercoralis ${ }^{13}$.

The clinical case assumes importance because it is a common and benign disease, but due to an unusual presentation, it was not diagnosed early. It is important to know the other manifestations of cutaneous larva migrans infection and its generalized form. The disseminated form may require hospitalization and prolonged treatment as presented.

\section{REFERENCES}

1. Loukas A, Hotez PJ, Diemert D, Yazdanbakhsh, McCarthy JS, Correa-Oliveira R, et al. Hookworm infection. Nature Reviews Disease Primers, 2016; (2): 1-18. PubMed PMID: 27929101. doi:10.1038/nrdp.2016.88.

2. Maguire JH. Intestinal nematodes (roundworms). In: Mandell GL, Bennet JE, Dolin R, editors. Principles and practice of infectious diseases, 7th editon, Philadelphia. Elsevier; 2010.p. 3577-3586.

3. González-Ramos J, González-Silva Y, Hernández-Cano N, Vidaurrázaga- 
Arcaya C, Herranz-Pinto P. Disseminated cutaneous larva migrans infestation. Semergen. 2015 Nov-Dec; 41(8):458-60. doi: 10.1016/j.semerg.2014.12.006.

4. Jackson A, Heukelbach J, Calheiros CM, Soares Vde L, Harms G, Feldmeier H. A study in a community in Brazil in which cutaneous larva migrans is endemic. Clin Infect Dis. 2006; 43(2):e13-8. PubMed PMID: 16779735. doi: 10.1086/505221.

5. Araújo FR, Araújo CP,Werneck MR, Górski A. Larva migrans cutânea em crianças de uma escola em área do Centro-Oeste do Brasil. Rev. Saúde Pública. 2000; 34(1): 84-85. doi: 10.1590/S0034-89102000000100015.

6. Sunderkötter C, von Stebut E, Schöfer H, Mempel M, Reinel D, Wolf G, Meyer V, Nast A, Burchard GD. S1 guideline diagnosis and therapy of cutaneous larva migrans (creeping disease). J Dtsch Dermatol Ges. 2014 Jan; 12(1): 86-91. PubMed PMID: 24393321 doi: 10.1111/ddg.12250.

7. Veraldi S, Çuka E, Pontini P, Vaira F. Bullous cutaneous larva migrans: case series and review of atypical clinical presentations. G Ital Dermatol Venereol. 2017 Oct; 152(5):516-519. PubMed PMID: 28906088. doi: 10.23736/S03920488.16.04832-X

8. Le Joncour A, Lacour SA, Lecso G, Regnier S, Guillot J, Caumes E. Case Report : Molecular Characterization of Ancylostoma braziliense Larvae in a Patient with Hookworm-Related Cutaneous Larva Migrans. Am J Trop Med Hyg. 2012 May;
86(5):843-845. PubMed PMID: 22556085. doi: 10.4269/ajtmh.2012.11-0734.

9. Tan SK, Liu TT. Cutaneous larva migrans complicated by Löffler syndrome. Arch Dermatol. 2010 Feb; 146(2):210-212. PubMed PMID: 20157045. doi:10.1001/ archdermatol.2009.392.

10. Jelinek T, Maiwald H, Nothdurft HD, Löscher T. Cutaneous larvamigrans in travelers: synopsis of histories, symptoms, and treatment of 98 patients.Clin Infect Dis. 1994 Dec; 19(6):1062-6. PubMed PMID: 7534125.

11. Vanhaecke C, Perignon A, Monsel G, Regnier S, Bricaire F, Caumes E.The efficacy of single dose ivermectin in the treatment of hookworm related cutaneous larva migrans varies depending on the clinical presentation. J Eur Acad Dermatol Venereol. 2014 May; 28(5): 655-657. PubMed PMID: 23368818. doi: $10.1111 /$ jdv.12097.

12. Veraldi S, Rizzitelli G. Effectiveness of a new therapeutic regimen with albendazole in cutaneous larva migrans. Eur J Dermatol. 1999 Jul-Aug; 9(5):352353. PubMed PMID: 10417435.

13. Ly MN, Bethel SL, Usmani AS, Lambert DR. Cutaneous Strongyloides stercoralis infection: an unusual presentation. J Am Acad Dermatol. 2003 Aug; 49(2 Suppl Case Reports):S157-60. PubMed PMID: 12894109.

\section{Como citar este artigo/How to cite this article:}

Lopes VV, Farias LABG, Rodrigues NBS, Moraes AP, Leite RD, Ferreira ML Disseminated cutaneous larva migrans in a 7-year-old patient. J Health Biol Sci. 2019 Jan-Mar; 7(1):101-103. 